\title{
Root Pass Microstructure in Super Duplex Stainless Steel Multipass Welds
}

\author{
The impact of GTAW multipass weld thermal cycles on the root pass fusion zone \\ austenite volume fraction and morphology in UNS32750 is detailed
}

\author{
BY T. PICKLE, N. HENRY, P. MORRISS, L. TENNIS, D. WAGNER, AND R. E. BAUMER
}

\begin{abstract}
Superduplex stainless steels (SDSS) have twice the base strength and pitting corrosion resistance of austenitic stainless steels and are commonly used when stresscorrosion cracking is a concern. During multipass welding of SDSS, a 50-50 austenite-ferrite phase balance is recommended in the exposed root pass fusion zone and heataffected zone (HAZ), although $35-65 \%$ of austenite is acceptable. Systematic studies with the arc energy and number of weld passes with mechanized multipass gas tungsten arc welding (GTAW) of 6-mm- (0.24-in.-) and 12.7-mm(0.5-in.-) thick substrates (UNS S32750) reveal that multiple thermal cycles experienced in the root result in an increased root fusion zone austenite-ferrite ratio and presence of secondary austenite. Gleeble ${ }^{\circledR} 1500$ physical reheating simulations, applying experimental thermal cycles directly measured in the root of multipass GTA welds, confirm these results.
\end{abstract}

\section{KEYWORDS}

- Duplex Stainless Steel • Secondary Austenite

- Gas Tungsten Arc Welding (GTAW) - Microstructure

\section{Introduction}

Superduplex stainless steels (SDSS) are Fe-Cr-Ni-N alloys with a dual-phase wrought microstructure consisting of approximately $50-50$ vol- $\%$ austenite/ferrite. This phase balance provides superior pitting corrosion resistance and twice the yield strength compared to standard austenitic stainless steels (Refs. 1, 2). As a result, SDSS are commonly used in applications that require high strength, toughness, and corrosion resistance where stress corrosion cracking (SCC) is a concern (Refs. 1-4). Welding of duplex stainless steel (DSS) significantly alters the engineered microstruc- ture, and has been reported to cause loss of corrosion resistance (Refs. 5-7) and reduced impact toughness (Refs. 5, 8). Detrimental property changes in the weld fusion zone (FZ) and heat-affected zone (HAZ) have been reported to originate from the following: deviation from a proper austenite/ ferrite microstructure phase balance (Ref. 9), composition (Refs. 7, 10), and formation of brittle secondary phases like the sigma $(\sigma)$ phase (Ref. 11). Base metal and filler composition, heat input (Refs. 4,12), dilution (Ref. 4), shielding gas (Refs. 12-15), cooling rates (i.e., rate of change of temperature with respect to time) (Refs. 16, 17), interpass temperatures in multipass welding (Ref. 4), and weld process type (Refs. 9, 18) are all important process variables that collectively influence the welded microstructure and the FZ and HAZ material properties (Ref. 3).

Maintaining a proper austenite/ferrite phase balance, while avoiding formation of embrittling phases (e.g., $\sigma$ ), is necessary to maintain acceptable weld FZ and HAZ toughness and corrosion resistance. Both nickel and nitrogen are austenite stabilizers, and researchers have investigated welding with overalloyed (nickel) filler metals (e.g., ER2594 on duplex 2205) (Refs. 13, 19) and nitrogen-containing shielding gases (Refs. 15, 20-22). Researchers have demonstrated that nitrogen loss from weld metal during welding reduces austenite content and reduces corrosion resistance (Refs. 23, 24), while intentional additions of nitrogen to argon shielding promotes austenite formation and can increase corrosion resistance (Refs. 20, 24).

The thermal history of the FZ and HAZ is also very important for microstructural phase balance. For DSS, the microstructure solidifies as $100 \%$ ferrite and then forms austenite in a diffusion-mediated phase transformation with the primary austenite forming between $800^{\circ}$ and $1200^{\circ} \mathrm{C}\left(1472^{\circ}\right.$ and $\left.2192^{\circ} \mathrm{F}\right)$, although it can form at temperatures up to $1350^{\circ} \mathrm{C}\left(2462^{\circ} \mathrm{F}\right)$ for superduplex grades (Refs. 25,26 ). As welding heat input (arc energy) increases, weld FZ and HAZ cooling rates decrease. Slower cooling rates increase the amount of time for austenite nucleation and growth in the $800^{\circ}-1200^{\circ} \mathrm{C}\left(1472^{\circ}-2192^{\circ} \mathrm{F}\right)$ temperature 


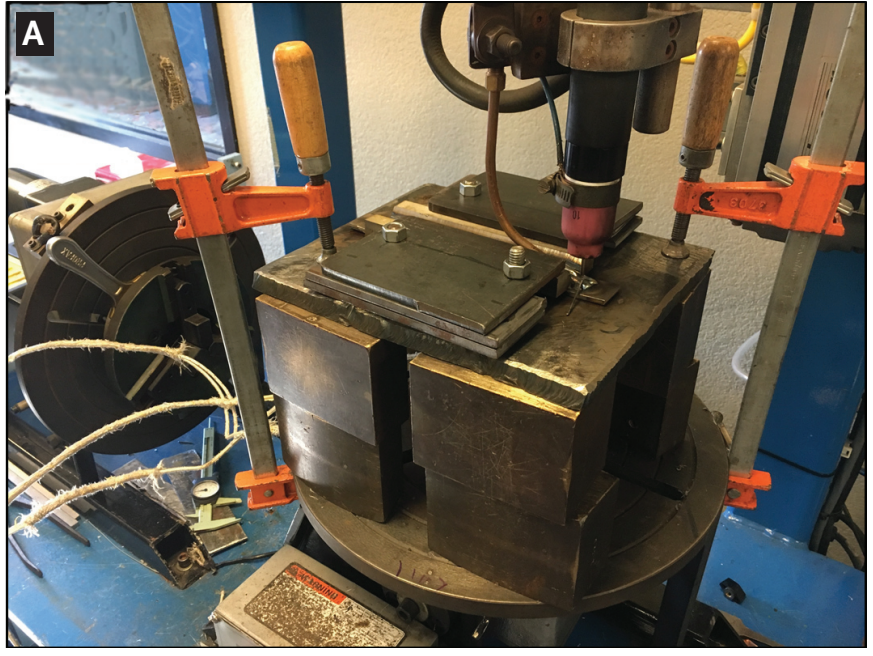

C

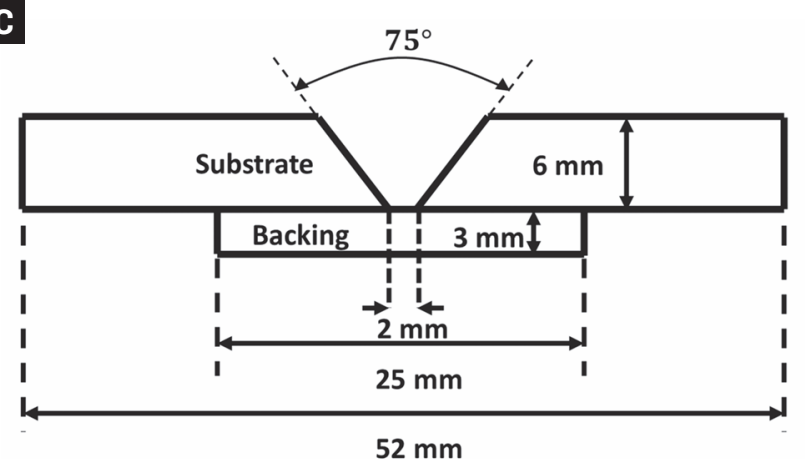

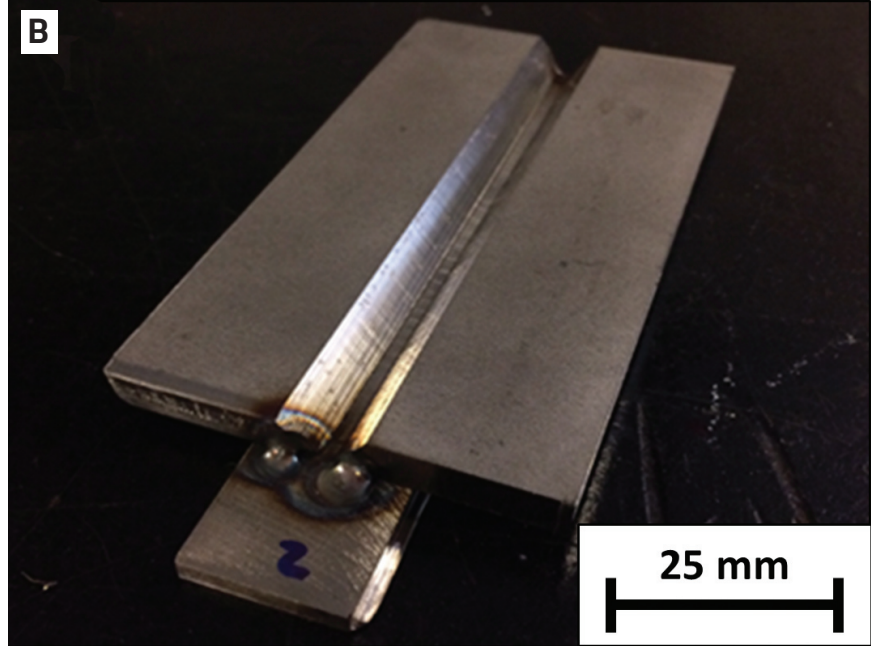

D

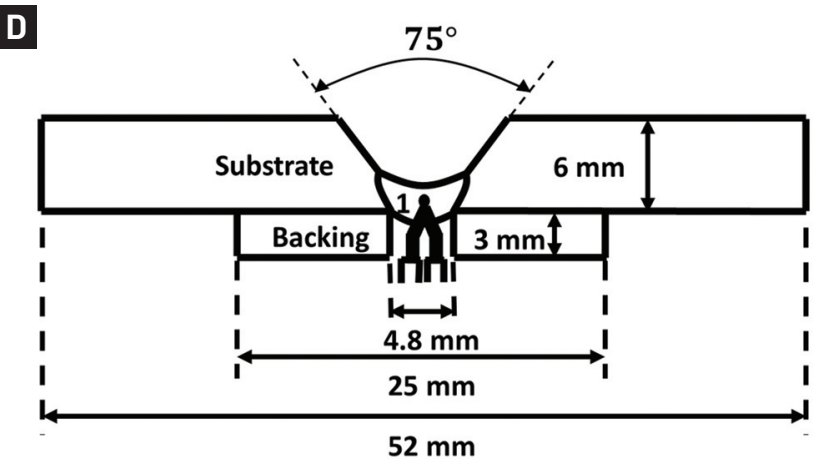

Fig. 1-Schematics showing experiment and sample setup: A - Mechanized GTAW fixture; B - 6-mm-thick substrate with 3-mm backing plate; $C$ - cross-section schematic of weld joint before root pass; and $D$ - cross-section schematic showing thermocouple location after completion of root pass weld.

range (Refs. 12, 16, 19). Similarly, multipass welding, which may reheat previously solidified weld zones to temperatures well above $800^{\circ} \mathrm{C}\left(1472^{\circ} \mathrm{F}\right)$, can induce significant microstructure and property changes, such as the formation of secondary austenite and/or possible formation of the sigma phase (Refs. 6, 17). Although previous studies have reported that reheating with autogenous welds or HAZ re-heating affects weld microstructure (Refs. 6, 17, 27), only a few have studied the change in root pass FZ austenite content caused by reheating thermal cycles from subsequent passes (Refs. $13,14)$. In pipeline applications of SDSS, the root pass FZ and HAZ are in direct contact with corrosive media. It is, therefore, of great importance to understand the impact of multipass thermal cycles on the root pass FZ and HAZ microstructure, specifically the austenite/ferrite ratio.

In this study, in-situ thermal measurements in the root of mechanized multipass gas tungsten arc welding (GTAW) on 6-mm- (0.24-in.-) and 12.7-mm- (0.5-in.-) thick UNS S32750 plates were performed, and the in-situ measured multiple reheating thermal cycles were correlated with microstructural evolution of austenite in the root pass FZ. To isolate the effect of solid-state reheating on austenite growth, in-situ measured thermal data from the root pass was used for Gleeble ${ }^{\circledR} 1500$ reheating simulations on aswelded bead-on-plate (BOP) microstructures. Results indicate the thermal cycle history significantly affects the final root pass austenite/ferrite ratio. Thermal cycle history is found to be additive to the known effect of nitrogen content in argon shielding gases. These findings suggest root-pass thermal history is an important consideration when developing welding procedures for superduplex stainless steels.

\section{Methodology}

Mechanized GTA welds were performed on 6-mm- and 6.35-mm-thick UNS S32750 (2507) substrates with premixed certified gases (100\% $\mathrm{Ar}, 98 \% \mathrm{Ar} / 2 \% \mathrm{~N}_{2}$, and $94 \% \mathrm{Ar} /$ $\left.6 \% \mathrm{~N}_{2}\right)$. Backing plates of UNS S32750, 3-3.13 mm (0.120.125 in.) thick, were used as shown in Fig. $1 B$ and C. All multipass welds had a maximum interpass temperature of $120^{\circ} \mathrm{C}\left(248^{\circ} \mathrm{F}\right)$. For all welds, nickel-enriched ER2594 1.2mm- (0.047-in.-) diameter filler metal was used. The details of each weld are tabulated in Table 1 . Table 2 shows the manufacturer-reported composition of the substrates, backing plates, and welding wire.

Figure 1A shows the mechanized GTA weld setup, including the heat sink and clamping system. All samples were cleaned with acetone prior to welding and wire brushed with stainlesssteel brushes before each weld pass. To obtain the austenite volume fraction, each sample was cross sectioned according to guidelines described in ASTM E3-11, polished to 6-micron diamond grit, etched with Beraha's II reagent (1-g potassium 
Table 1 - Welding Parameters Used for Each Individual Weld

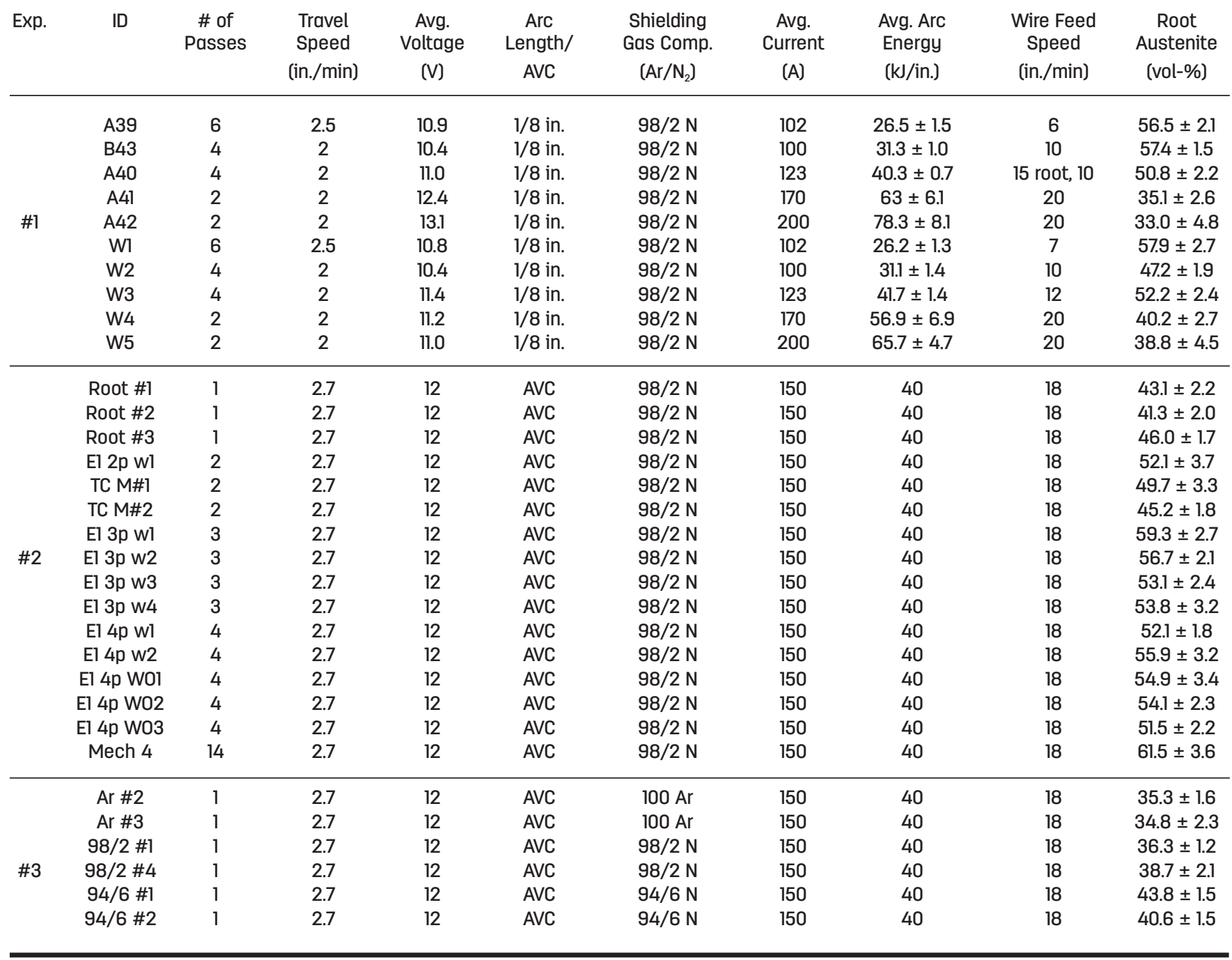

*Exp. 1 welds used a $1 / 8$ in., $2 \%$ thoriated tungsten and shielding gas $30 \mathrm{ft}^{3} / \mathrm{h}$ flow rate while Exp. 2 and 3 welds used a $3 / 32$ in., $2 \%$ lanthanated tungsten electrode and 19 $\mathrm{ft}^{3} / \mathrm{h}$ flow rate. Each electrode was precision ground to a 40 - deg electrode angle with $\mathrm{a} \% / 8$ in. tungsten stickout. AVC indicates automated voltage control, which automatically adjusted arc length to maintain voltage.

metabisulfite, 20-mL HCL, and 100-mL $\mathrm{H}_{2} \mathrm{O}$ ), and analyzed using light optical microscopy at $500 \times$ magnification. The volumetric fraction of austenite was calculated using JMicroVision digital image analysis software (Ref. 28) with a minimum of 10 pictures per zone. Images were converted to grayscale, phases extracted and calculated, and results averaged to obtain overall austenite fraction with methods similar to that reported by Zhang et al. (Ref. 14). An example of austenite phase calculation is shown in Fig. 2. All austenite volume fraction data reported in the text corresponds to an average value and standard deviation (minimum ten fields of view).

\section{Experiment \#1: 6-mm (0.24-in.) GTAW Multipass Welds with Varied Arc Energy}

In Experiment 1, mechanized GTAW was performed on 6mm- (0.24-in.-) thick UNS S32750 with a 75-deg single-V joint, 2-mm (0.08-in.) root opening, and 3-mm- (0.12-in.-) thick UNS S32750 backing plate (Fig. 1B and C), using an average arc energy of $26,31,41,57,64$, and $78 \mathrm{~kJ} /$ in. per pass per weld specimen. Arc energy is taken to be the total weld energy per length and was calculated as $I \cdot V \cdot 60 / v$, where $V$ is voltage [volts], $I$ is current [amperes], and $v$ is travel speed [in./min]. Welding heat input includes an arc efficiency factor, $\eta$, to account for heat loss (i.e., convection and radiation) to the weld area, which has been calculated to be 0.81 for a GTAW process using a calorimetric method (Ref. 17). Since the heat sinks for welding experiments may vary, theoretical arc energy (i.e., $\eta=$ 1 ) is used to describe the heat input for the weld process in this work. Travel speed was held constant at $2 \mathrm{in} . / \mathrm{min}$ (except with $2.5 \mathrm{in} . / \mathrm{min}$ for $26 \mathrm{~kJ} / \mathrm{in}$.), and voltage varied only slightly between experiments (11-14 V) at a fixed arc length of 3.2 $\mathrm{mm}$ (0.125 in.). Arc energy was controlled by varying current from 100 to $200 \mathrm{~A}$. A shielding gas composition of $98 \% \mathrm{Ar} / 2 \%$ $\mathrm{N}_{2}$ was used at a flow rate of $14 \mathrm{~L} / \mathrm{min}\left(30 \mathrm{ft}^{3} / \mathrm{h}\right)$. 

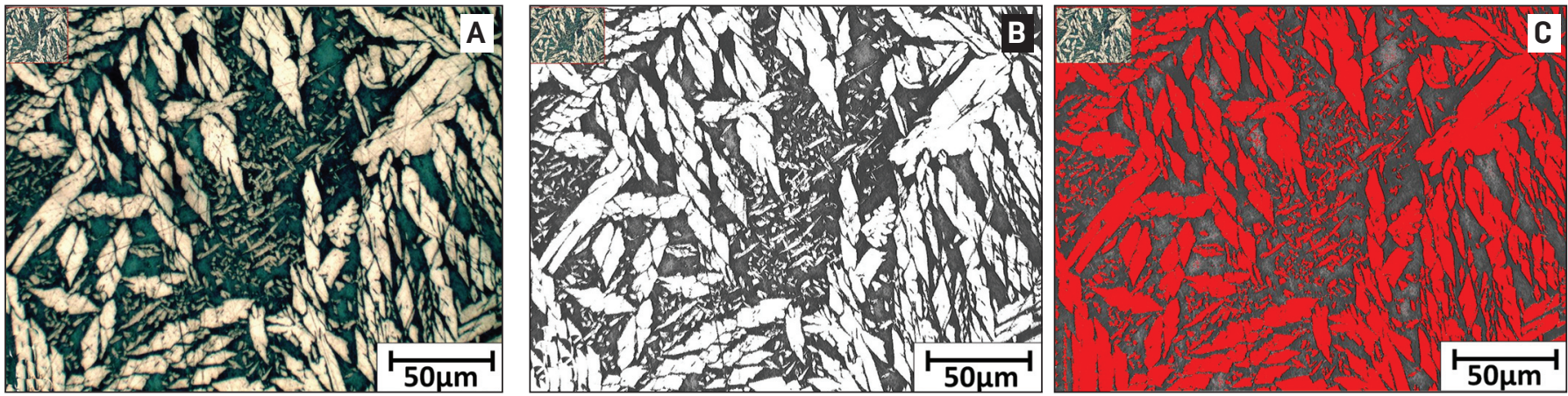

Fig. 2 - A - Example as-etched microstructure (Beraha's II reagent); B - example grayscale image of sample; and C - red highlighted area used to calculate austenite-ferrite ratio in JMicroVision.

Table 2 - Composition of Substrate, Backing, and Filler Materials Used for Experiments 1-3

Material

\begin{tabular}{ccccccccccc} 
C & \multicolumn{10}{c}{ Composition (wt-\%) } \\
& $\mathrm{Cr}$ & $\mathrm{Ni}$ & $\mathrm{Mo}$ & $\mathrm{N}$ & $\mathrm{Cu}$ & $\mathrm{Si}$ & $\mathrm{Mn}$ & $\mathrm{P}$ & $\mathrm{S}$ & $\mathrm{Ti}$ \\
0.015 & 24.96 & 6.93 & 3.81 & 0.28 & 0.24 & 0.34 & 0.78 & 0.029 & 0.001 & 0.007 \\
0.016 & 25.04 & 6.93 & 3.78 & 0.27 & 0.4 & 0.44 & 0.76 & 0.028 & 0.001 & 0.009 \\
0.02 & 24.8 & 6.6 & 3.7 & 0.28 & 0.16 & 0.35 & 0.82 & 0.024 & 0.0003 & - \\
0.019 & 25.64 & 6.95 & 3.8 & 0.28 & 0.25 & 0.25 & 0.59 & 0.025 & 0.0003 & - \\
0.02 & 24.8 & 6.6 & 3.7 & 0.28 & 0.16 & 0.35 & 0.82 & 0.024 & 0.0003 & - \\
0.02 & 25 & 9.5 & 4.0 & 0.25 & - & 0.35 & 0.4 & - & - & - \\
& & & & & & & & & & -
\end{tabular}

(a) Experiment 1, (b) Experiment 2, (c) Experiment 3

Deposition rates and wire feed speed (WFS) were higher with the higher arc energy (20 in./min WFS) than lower arc energies (6 in./min WFS), requiring fewer passes ( 2 passes) than the lower arc energy welds ( 6 passes) to fill the $6-\mathrm{mm}$ (0.12-in.-) thick joint (Fig. 3B). A 3.2-mm- (0.125-in.-) diameter $2 \%$ thoriated electrode was used for this experiment with the electrode tip centered in the joint for the root pass, and with split passes for the 4- and 6-pass welds - Fig. 3B. Austenite volume fraction measurements were obtained as described above.

\section{Experiment \#2: 6-mm (0.24-in.) and 12.7-mm (0.5-in.) Multipass Welds with Constant Arc Energy and Varied Number of Passes}

In Experiment 2, 4-pass welds with a 40-kJ/in. arc energy (12 V, $150 \mathrm{~A}, 2.7 \mathrm{in.} / \mathrm{min}$ ) and a wire feed speed of $18 \mathrm{in.} / \mathrm{min}$ were performed with a $98 \% \mathrm{Ar} / 2 \% \mathrm{~N}_{2}$ shielding gas with a gas flow rate of $9 \mathrm{~L} / \mathrm{min}\left(19 \mathrm{ft}^{3} / \mathrm{h}\right)$. A 2.4-mm ( $3 / 32$-in.) 2\% lanthanated tungsten electrode was used for this experiment. To analyze how the root FZ microstructure changes with subsequent passes, three welds were made with just the root pass before cross-sectional analysis, three welds with 2 passes, four welds with 3 passes, and seven welds with 4 passes (Fig. 4B). Weld specimens were cross sectioned in the middle of the weld specimen and austenite volume fraction measured in both the weld root and subsequent pass FZ regions. For in-situ thermal data of the initial root weld, K-type thermocouples were plunged into the molten pool root pass welds to measure cool- ing rates. The high-temperature accuracy of the K-type thermocouples (Omega Instruments) was validated by measuring the melting point of $99.9 \%$ pure copper (McMaster-Carr), finding an average of $1079 \pm 19.0^{\circ} \mathrm{C}\left(1974 \pm 66^{\circ} \mathrm{F}\right)$, compared to the known melting point of $1084.6^{\circ} \mathrm{C}\left(1985^{\circ} \mathrm{F}\right)$ (Ref. 29). All thermal data was collected with a National Instruments data acquisition system at a sampling frequency of $4 \mathrm{~Hz}$.

Following completion of the initial root pass weld, $4.8-\mathrm{mm}$ (0.19-in.-) diameter holes were drilled through the backing plate and root pass. Thermocouples were embedded from the backing plate side, approximately $1.2 \mathrm{~mm}$ (0.047 in.) above the interface between the substrate and backing, and manually welded in place from the root side using GTAW and 3.2-mm(0.13-in.-) diameter ER2594 filler. Plug welds were ground flush with the rest of the root pass. Between three to four thermocouples were embedded in each root pass, $\sim 38 \mathrm{~mm}$ (1.5 in.) apart, and enabled direct measurement of the root pass FZ time and temperature data during subsequent weld passes - Fig. 1D and Fig. 4B, 1-4. The rate of change of temperature per time (i.e., cooling rate) in the $\mathrm{FZ}$ was calculated using a linear fit between $1200^{\circ}$ and $800^{\circ} \mathrm{C}\left(2192^{\circ}\right.$ and $\left.1472^{\circ} \mathrm{F}\right)$. After welding, samples were cross sectioned at thermocouple locations to determine the distance from the thermocouple tip to the FZ boundary of each subsequent pass. To analyze the effect of a thicker plate on the thermal history in the root pass, a mechanized GTA weld was then performed on 12.7-mm- (0.5-in.-) thick UNS S32750 plate with the same joint geometry, backing plate, $40 \mathrm{~kJ} / \mathrm{in}$. arc energy, and welding parameters described for 6-mm (0.24-in.) welds. For a constant arc energy of $40 \mathrm{~kJ} / \mathrm{in}$. and wire feed speed of 18 


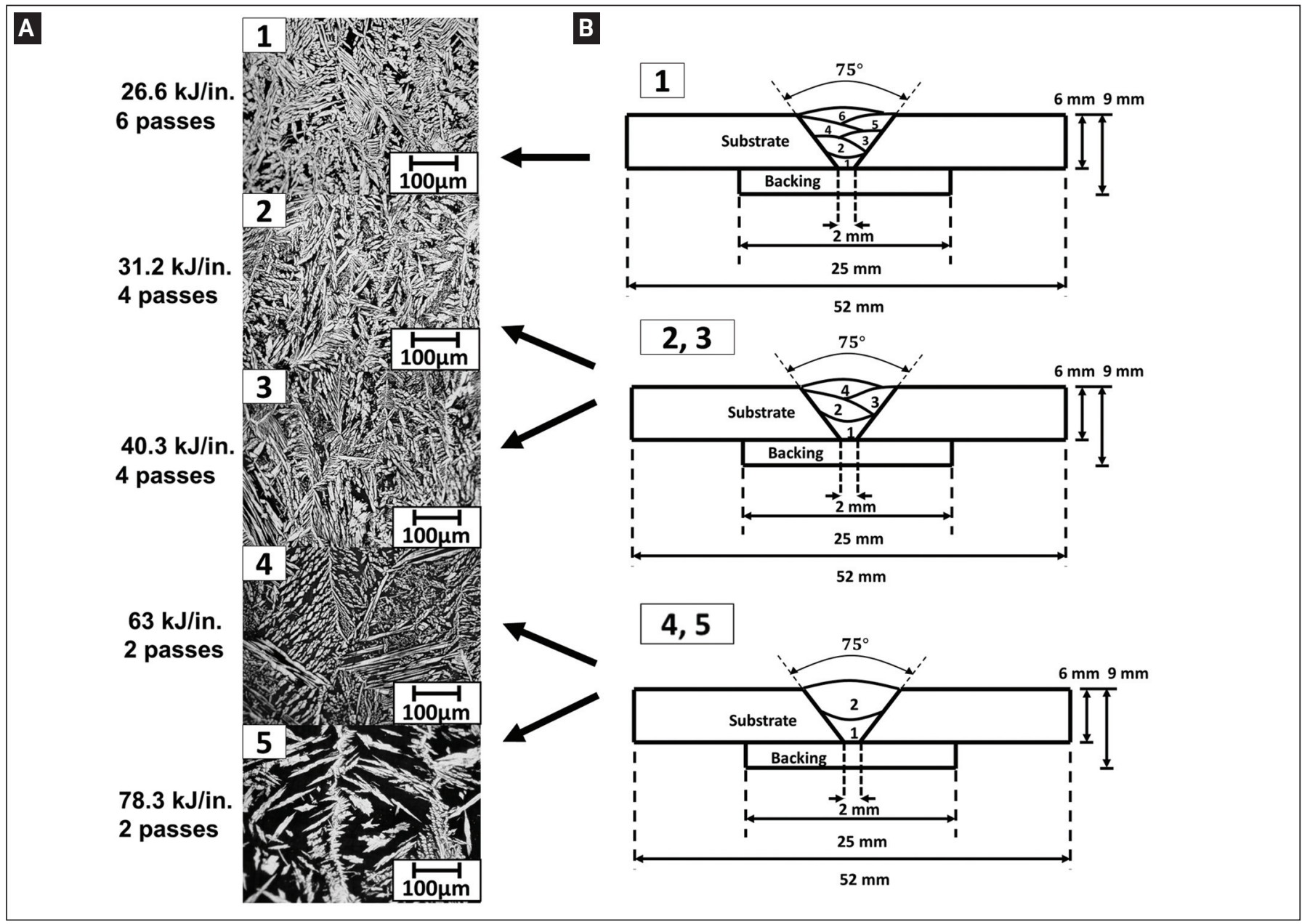

Fig. 3 - Experiment 1 : A - Root pass FZ microstructures after completion of weld showing a 25\% increase in austenite percentage from $A 5$ to $A l ; B$ - weld specimen geometry for all welds showing split passes for 4- and 6-pass welds.

in./min, 14 passes were required to fill the joint. The first two passes were centered on the root, while the rest of the passes were staggered in rows of 2-3 passes with 3 passes at the top of the joint. The root pass FZ thermal cycle data was obtained for passes 2-6, following the same methodology for the 6- and 6.35 -mm multipass welds.

\section{Experiment \#3: Single-Pass Bead-on-Plate Welds and Gleeble Thermal Simulations}

Single-pass BOP welds on 3.15-mm- (0.125-in.-) thick [150-mm-long $\times 50$-mm-wide $(6-\times 2$-in.) $]$ plates with ER2594 welding wire were made using a $100 \% \mathrm{Ar}, 98 \% \mathrm{Ar}-$ $2 \% \mathrm{~N}_{2}$, or $94 \% \mathrm{Ar}-6 \% \mathrm{~N}_{2}$ shielding gas, all with a flow rate of $9 \mathrm{~L} / \mathrm{min}\left(19 \mathrm{ft}^{3} / \mathrm{h}\right)$, to observe the effect of nitrogen shielding gas content on the austenite vol-\%. All other process parameters (40 kJ/in., deposition rate, and electrode) were identical to Experiment 2 (see Table 1).

K-type thermocouples were plunged in the fusion zone in the BOP welds to enable comparison of cooling rates in BOP as-welded FZ microstructures to that measured in the root pass FZ of Experiment 2 welds. The BOP welds were cross sectioned into six total $25-\times 76-\mathrm{mm}(1-\times 3$-in.) specimens per shielding gas (three per plate; two BOP welds per shielding gas composition), and each specimen was used for physical reheating simulations. Using the in-situ measured average thermal cycles experienced in the root pass FZ in the multipass weld of Experiment 2, a Gleeble 1500 thermo-mechanical simulator was used to perform one, two, or three reheating cycles on BOP samples in a chamber with $100 \%$ Ar, $98 \%$ Ar- $2 \% \mathrm{~N}_{2}$, or $94 \%$ Ar- $6 \% \mathrm{~N}_{2}$ shielding gas environments matching the original BOP weld shielding gas. Before each experiment, the 0.028 $\mathrm{m}^{3}\left(0.6 \mathrm{ft}^{3}\right)$ Gleeble chamber was purged using a $14 \mathrm{~L} / \mathrm{min}$ (30 $\mathrm{ft}^{3} / \mathrm{h}$ ) flow rate for $1.2 \mathrm{~min}$ (until filled), and then continually purged at the same flow rate until the sample cooled below $500^{\circ} \mathrm{C}\left(932^{\circ} \mathrm{F}\right)$. The resultant microstructure before and after each reheating cycle, particularly the austenite volume fraction and morphology, was analyzed and compared with the actual weld root pass results from Experiment 2.

\section{Results}

\section{Experiment \#1: Multipass Welds with Varied Arc Energy}

As shown in Figs. 3A and 5A, the austenite vol-\% in the root pass FZ decreases with increasing arc energy. Howev- 


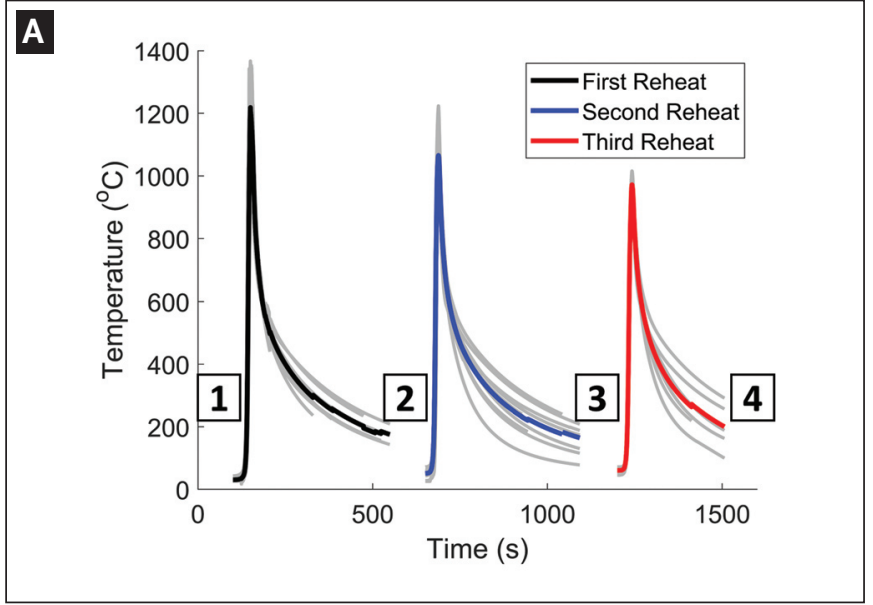

Fig. 4 - Experiment 2 results with a constant heat input per pass (40 kJ/in.) showing the following: $A$ - In-situ root pass time and temperature reheating measurements; $B-$ schematic of cross-section geometry for each subsequent weld pass with relative thermocouple location; and $\mathrm{C}-$ root microstructure evolution showing increased austenite after subsequent passes.

er, when replotted as a function of the number of passes, the root pass $\mathrm{FZ}$ austenite content increases significantly with increased number of reheated thermal cycles - Fig. $5 \mathrm{~B}$. As the number of passes increased from 2 (highest arc energy) to 6 passes (lowest arc energy), the total root pass FZ austenite vol-\% increased from a minimum of $33 \%$ to as high as $58 \%$ austenite. For welds made with more passes and a lower arc energy, the root pass FZ microstructure has a significant austenite content increase due to formation of secondary austenite, as well as more primary grain boundary allotriomorphic and Widmanstätten austenite - Fig. 3A, 1. Following previous work (Ref. 20), secondary austenite is identified as intragranular austenite particles located within ferrite grains, such as shown in the root
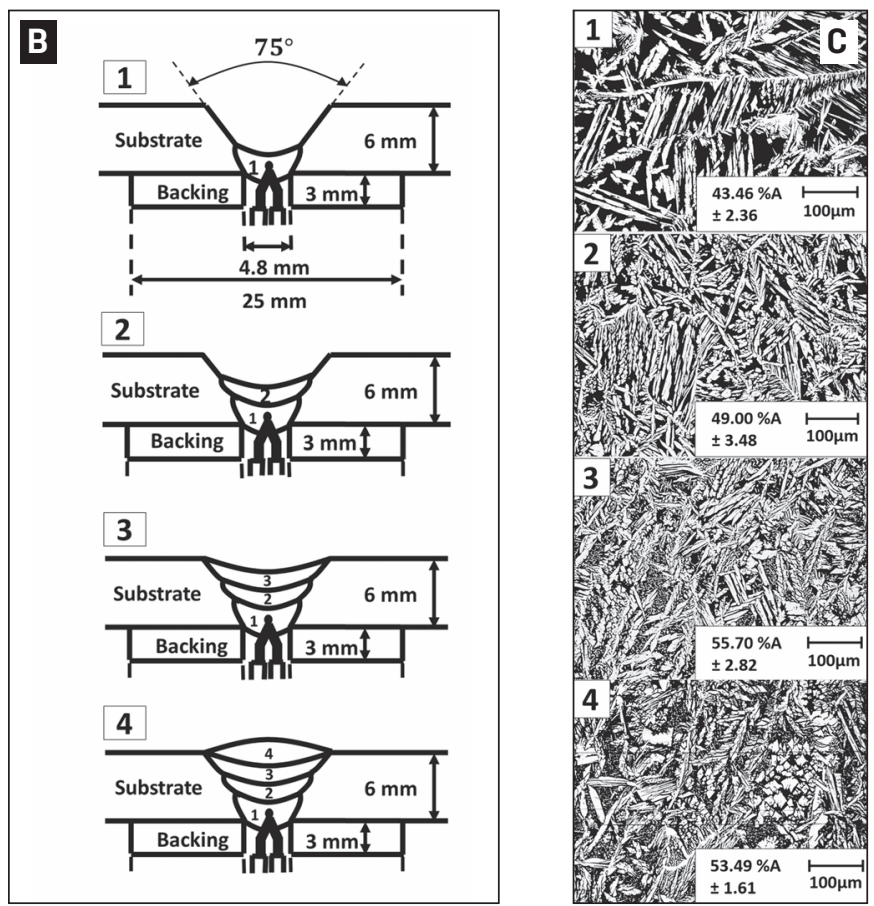

pass FZ microstructures in Fig. 2. Based on the results of Experiment 1, it was hypothesized that the root pass (during multipass welding) is reheated by subsequent passes with temperatures sufficiently high as to cause intragranular secondary austenite formation and increased total austenite content. To test this hypothesis, the $40 \mathrm{~kJ} / \mathrm{in}$. arc energy condition from Experiment 1 was selected for further study.

\section{Experiment \#2: Multipass Welds with Constant Arc Energy}

In Experiment 2, the $40 \mathrm{~kJ} / \mathrm{in}$. (requiring 4 total passes) experiment was repeated with thermocouples embedded in

Table 3 - Measured Thermal Data from the Root Pass of Experiment 2 and Measured Austenite Vol-\% in the FZ of Each Weld Zone Region

\begin{tabular}{|c|c|c|c|c|c|c|c|}
\hline \multirow[b]{2}{*}{$\begin{array}{l}\text { \# Weld } \\
\text { Passes }\end{array}$} & \multirow[b]{2}{*}{ Zone* } & \multirow[b]{2}{*}{$\begin{array}{c}\text { Austenite } \\
\text { Volume [\%] }\end{array}$} & \multicolumn{5}{|c|}{ Root Pass $T(t)$} \\
\hline & & & $\begin{array}{c}\text { Heating } \\
\text { Rate }\left[^{\circ} \mathrm{C} / \mathrm{s}\right]\end{array}$ & $\begin{array}{c}\text { Cooling } \\
\text { Rate }\left[^{\circ} \mathrm{C} / \mathrm{s}\right]\end{array}$ & $\begin{array}{l}\text { Cooling Time } \\
\text { above } 800^{\circ} \mathrm{C}[\mathrm{s}]\end{array}$ & $\begin{array}{l}\text { Total time T > } \\
800^{\circ} \mathrm{C}[\mathrm{s}]\end{array}$ & $\begin{array}{c}\text { Peak } \\
\text { Temp. }\left[{ }^{\circ} \mathrm{C}\right]\end{array}$ \\
\hline \multirow[t]{2}{*}{1} & 1 & $43.5 \pm 2.0$ & - & $25.1 \pm 3.4$ & $16 \pm 2.0$ & - & - \\
\hline & 1 & $49 \pm 2.6$ & & & & & \\
\hline \multirow[t]{2}{*}{2} & 2 & $46.7 \pm 2.7$ & $109.6 \pm 21.2$ & $31.3 \pm 3.6$ & $13.3 \pm 2.7$ & $17.2 \pm 2.9$ & $1218.8 \pm 104.4$ \\
\hline & 1 & $55.7 \pm 2.8$ & & & & & \\
\hline \multirow[t]{2}{*}{3} & 2 & $55.6 \pm 4.3$ & $77 \pm 16.7$ & $26.0 \pm 7.2$ & $10.2 \pm 2.1$ & $13.7 \pm 2.8$ & $1065.0 \pm$ \\
\hline & $\begin{array}{l}1 \\
2\end{array}$ & $\begin{array}{c}53.5 \pm 1.6 \\
58 \pm 3.1\end{array}$ & & & & & \\
\hline \multirow[t]{2}{*}{4} & 3 & $53.4 \pm 1.9$ & $61.6 \pm 4.5$ & $21.1 \pm 7.4$ & $8.3 \pm 1.7$ & $11.1 \pm 2.0$ & $972.0 \pm$ \\
\hline & 4 & 47. \pm 2.2 & & & & & 49.5 \\
\hline
\end{tabular}

*Zone 1 = root pass, zone $2=2^{\text {nd }}$ pass, etc., as shown in Fig. $4 \mathrm{~B}$

${ }^{*}$ Heating and cooling rates are based on linear fits between $100^{\circ} \mathrm{C}$ and $T_{\max }$ and $T_{\max }$ and $800^{\circ} \mathrm{C}$, respectively. The cooling time and total time above the critical temperature of $800^{\circ} \mathrm{C}$ are also shown. 

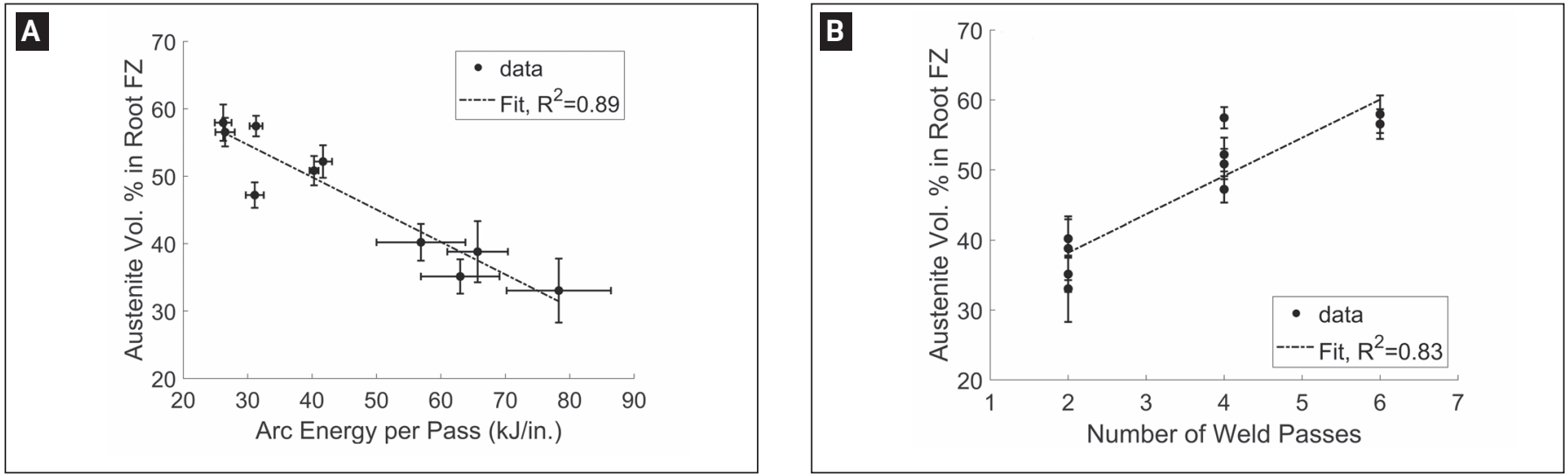

Fig. 5-A - Root austenite content as a function of heat input; B - total number of thermal cycles experienced in the root pass.

\section{A}

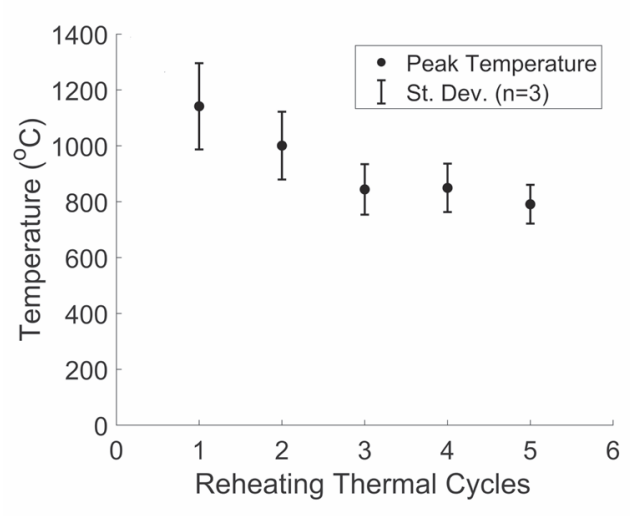

B

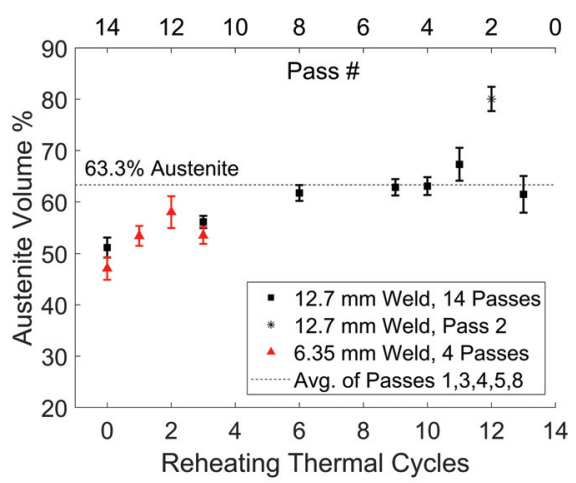

Fig. 6 - The 12.7-mm (0.5-in.) mechanized GTAW results: A - Measured root pass reheating thermal cycles for passes 2-6 at an average heat input of $40 \mathrm{~kJ} / \mathrm{in}$.; $B$ - mechanized 12.7- $\mathrm{mm}(0.5-\mathrm{in}$.) $40 \mathrm{~kJ} / \mathrm{in}$. per pass austenite vol-\% vs. number of reheating thermal cycles compared with 6.35- $\mathrm{mm}$ - (0.25-in.-) thick plate results from Experiment 2. Pass 2 shows an $80.1 \pm 2.4$ austenite \% and is considered not representative (see text).

the root pass to obtain in-situ measurements of the thermal cycle experienced by the root pass FZ. The measured temperature response is shown as thin gray lines in Fig. 4A, with the average thermal data from each welded sample shown in a bold colored line. The peak temperature and cooling rate data are presented in Table 3 . The scatter in peak temperature for individual welds is linearly related to the distance of the thermocouple relative to the bottom fusion boundary of each subsequent pass (analysis not shown). Peak temperatures measured in the root FZ were $1218 \pm 104.4^{\circ} \mathrm{C}\left(2224 \pm 220^{\circ} \mathrm{F}\right)$ during pass $2,1065.0 \pm$ $80.6^{\circ} \mathrm{C}\left(1949 \pm 177^{\circ} \mathrm{F}\right)$ during pass 3 , and $972.0 \pm 49.5^{\circ} \mathrm{C}$ $\left(1782 \pm 121^{\circ} \mathrm{F}\right)$ during pass 4 . Heating rate, peak temperature, and cooling rate decrease with each subsequent pass. The average total time spent at temperatures above $800^{\circ} \mathrm{C}$ $\left(1472^{\circ} \mathrm{F}\right)$ was calculated to be $58 \mathrm{~s}$, including the initial cooling of the root pass.

Analysis of the microstructure and austenite morphology of the root pass FZ after each subsequent weld pass was performed for four cases: 1) root pass only; 2) root pass and second pass; 3 ) root pass and two additional passes ( 3 total); and 4) root pass and 3 additional passes ( 4 total) (Fig. 4B, 1-4). Representative micrographs from the root pass are presented in Fig. 4C, 1-4. The average starting austenite content in the root pass $\mathrm{FZ}$ is $43.5 \pm 2.4 \%$ - Fig. $4 \mathrm{C}, 1$. Following both the second and third pass, an increase of 5-6 vol-\% austenite was found in the root pass FZ, with vol-\% austenite values of 49.0 $\pm 3.5 \%$ and $55.7 \pm 2.8 \%$ measured in the root pass $\mathrm{FZ}$ after the second and third pass, respectively - Fig. 4C, 2 and 3. However, an average slight decrease of $2 \%$ austenite content to $53.5 \pm$ 1.6 vol-\% austenite was observed in the root after the fourth pass, which is hypothesized to be due to intragranular secondary austenite morphology changes - Fig. 4C, 4. In the second and third pass regions, a similar trend of increasing levels of austenite was seen following subsequent passes (Table 3). For instance, the $2^{\text {nd }}$ pass FZ (denoted as zone 2 ) experiences an average $8.9 \%$ increase in austenite after completion of 1 subsequent pass. Formation of intragranular secondary austenite formation was observed in the root pass FZ after only one additional thermal cycle (compare Fig. 4C, 1 to 2), leading to a final morphology (Fig. 4C, 4) that is very consistent with observations from Experiment 1 - see Fig. 3A, 3.

Similar trends were seen with the 12.7-mm (0.5-in.) mechanized GTA weld. The peak temperatures experienced in the root pass for 5 additional thermal cycles are shown in Fig. 6A. The peak temperatures in the root pass (average of three thermocouple readings) are $1142 \pm 154^{\circ} \mathrm{C}$ (2088 \pm $\left.309^{\circ} \mathrm{F}\right), 1001 \pm 121^{\circ} \mathrm{C}\left(1834 \pm 250^{\circ} \mathrm{F}\right), 844 \pm 90.4^{\circ} \mathrm{C}(1551 \pm$ $\left.195^{\circ} \mathrm{F}\right), 849 \pm 87^{\circ} \mathrm{C}\left(1560 \pm 189^{\circ} \mathrm{F}\right)$, and $791 \pm 69^{\circ} \mathrm{C}(1456 \pm$ $156^{\circ} \mathrm{F}$ ) for passes $2-6$, respectively. 


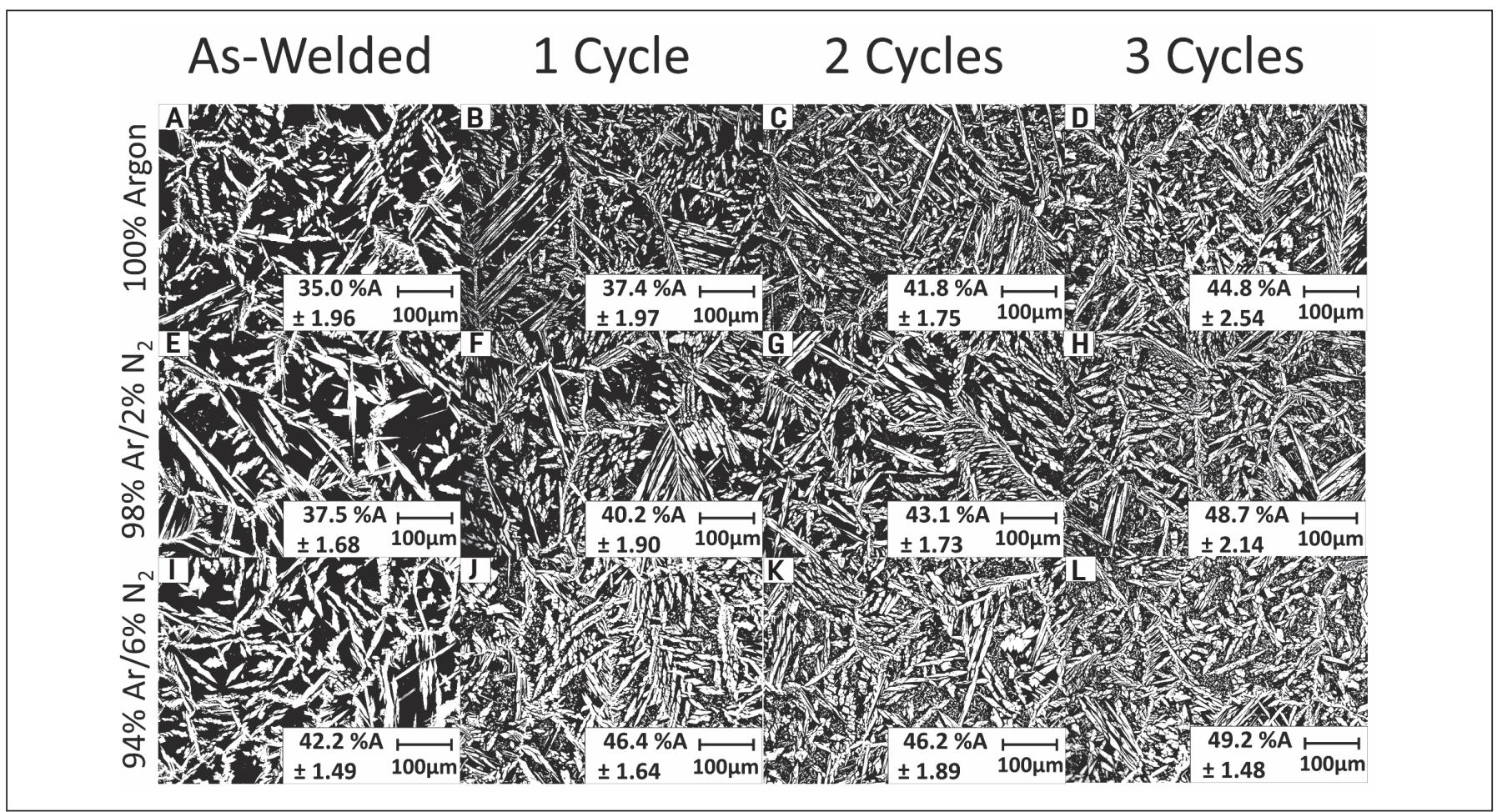

Fig. 7 - Experiment 3 results showing microstructure evolution for single-pass BOP as-welded FZ and Gleeble thermal cycles in the same location.

The austenite content for the 12.7-mm (0.5-in.) plate was quantified across the weld from the root to the cap pass. Figure $6 \mathrm{~B}$ shows the austenite volume fraction, measured with optical microscopy, plotted as a function of the number of thermal cycles experienced for each of the 14 passes. The weld that experiences no reheating (the top pass) is labeled as 0 , while the weld that experiences the most reheating cycles is the root (labeled as 13). The lowest austenite volume fraction is found in the top pass, with an average of $51.2 \pm 2.0 \%$ austenite ( 0 reheat thermal cycles). After approximately 5 reheating cycles, the austenite content is approximately constant, as indicated by the dashed line $(63.3 \pm 2.4 \%$, average of passes $1,3,4,5$, and 8). The surprisingly high percentage of $80.0 \pm 2.4 \%$ austenite in the second pass (asterisk symbol) is likely the result of a weld defect, as the microstructure has a ferrite interdendritic morphology similar to austenitic stainless steel (i.e., qualitatively different from other passes) and is therefore considered to not be representative. The $6.35-\mathrm{mm}$ (0.25-in.), 4-pass weld austenite results [same process conditions per pass as the 14-pass, 12.7 -mm (0.5-in.) weld] are plotted for comparison and show similar results.

\section{Experiment \#3: Single-Pass Bead-on-Plate Welds and Gleeble Simulations}

The data presented in Experiment 2 suggests that reheating plays an important role for microstructure evolution. However, given the complexity of multipass welding, it is desirable to isolate the role of composition and thermal cycles on root pass FZ microstructure evolution. Therefore, BOP welds were completed with 3.18-mm- (0.125-in.-) thick UNS S32750 plates to give samples for Gleeble reheat experiments. In the BOP specimens, the average dilution of the weld metal is $80 \pm$ $2.5 \%$ in comparison to the dilution of $54.0 \pm 2.8 \%$ measured for the root pass in Experiment 2 multipass welds. The aswelded BOP microstructures are presented in Fig. 7 and qualitatively similar to microstructures found in the Experiment 2 root pass FZ: primary grain boundary austenite with Widmanstätten side plates (compare Fig. 7E to Fig. 4C, 1). The austenite content in BOP FZ is lower than that measured in root pass FZ microstructures of Experiment 2 multipass welds, likely reflecting the increased dilution values in the BOP welds, given that the cooling rates from the plunged thermocouple data are close [see Table $3,25.1 \pm 3.4^{\circ} \mathrm{C} / \mathrm{s}(77.2 \pm$ $\left.38.1^{\circ} \mathrm{F} / \mathrm{s}\right)$ for Experiment 2; $30.5 \pm 10.6^{\circ} \mathrm{C} / \mathrm{s}\left(86.9 \pm 51.1^{\circ} \mathrm{F} / \mathrm{s}\right)$ measured in Experiment 3 BOP welds]. However, given the qualitative similarities in microstructure between BOP and multipass weld FZ microstructures, the BOP welds were considered sufficiently representative to use with physical simulation reheating studies.

Using the root thermal cycle data obtained in Experiment 2 , the as-welded BOP microstructures were reheated with a Gleeble 1500 thermo-mechanical simulator using the in-situ root pass measured thermal cycle from Experiment 2. For the three different shielding gases, 1, 2, or 3 thermal cycles (dark, thick lines in Fig. 4A) were applied and microstructure data obtained in the center of the reheated sample (at the control thermocouple location). For all shielding gas types, austenite content increases linearly by approximately $2-4 \%$ with each additional reheating thermal cycle - Fig. 8A. After 3 reheating thermal cycles, the total average austenite content increased $9.3 \%$ for all shielding gas types, compared to the $10 \%$ austenite content seen in the root FZ of Experiment 2. Figures 7 and 8 show that additions in nitrogen shielding gas content 

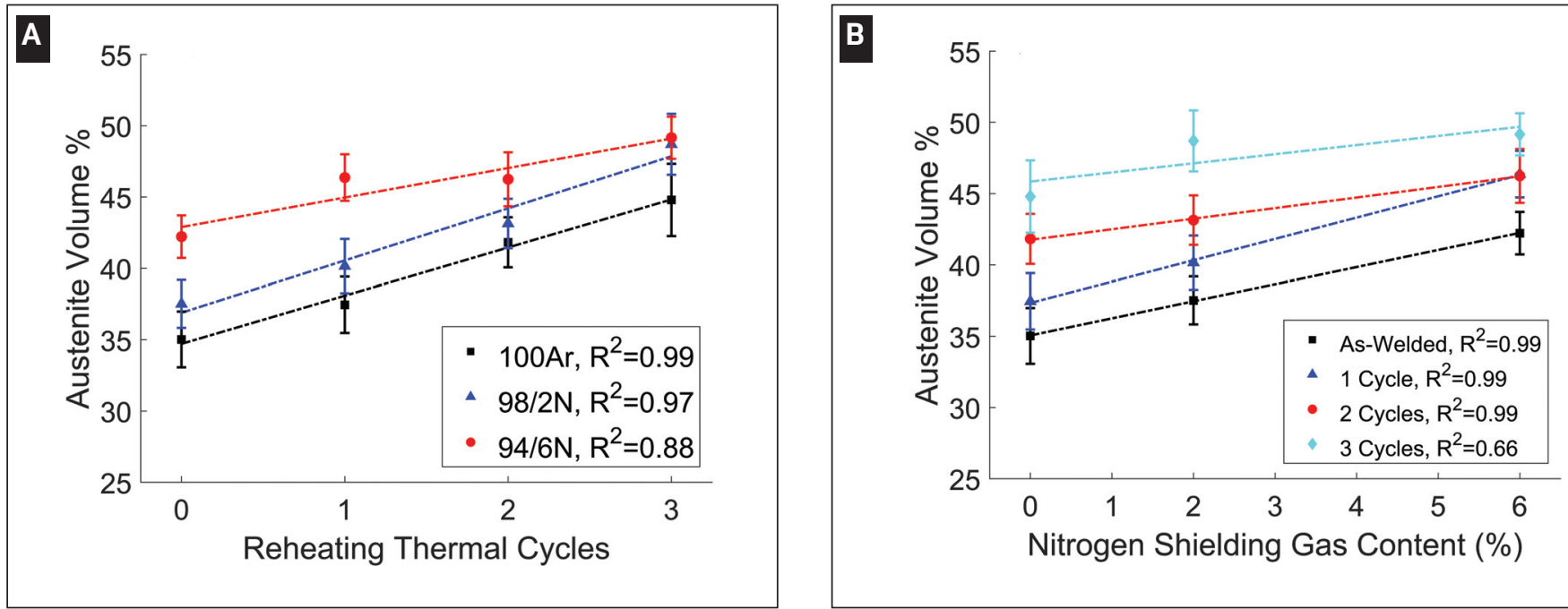

Fig. 8 - Austenite volume fraction in BOP fusion-zone welds following Gleeble reheating thermal cycles: A - Austenite increase as a function of reheated thermal cycles; B - austenite increase from increasing nitrogen content in shielding gas.

have a direct correlation with increased primary austenite content in the as-welded fusion zone of the single-pass BOP welds. With weld parameters held constant, the increase in shielding gas nitrogen content showed a linear increase of $2 \%$ in austenite content with every increase in $2 \%$ nitrogen shielding gas content (ranging from 34.5 to $42.2 \%$ austenite for aswelded microstructures) - Fig. 8B.

The as-welded austenite morphologies for each type of shielding gas show a Widmanstätten microstructure (Fig. 7A, $\mathrm{E}$, and I) similar to the microstructure from the root pass from Experiment 2 - Fig. 4C, 1. After one reheating cycle, significant intragranular secondary austenite growth was observed within the ferrite grains - Fig. 7B, F, and J. Subsequent reheating cycles correlate with continued secondary austenite growth, with extensive formation of fine austenite particles $\sim 1-5 \mu \mathrm{m}$ in diameter forming inside the ferrite matrix.

\section{Discussion}

\section{Role of Thermal Cycles}

The data obtained in Experiment 1, demonstrating decreasing austenite content with increasing arc energy (Fig. $5 \mathrm{~A}$ ), is surprising, given the well-established results from previous studies that have demonstrated austenite content increases with slower cooling rate thermal cycles and higher arc energies in the weld metal and HAZ (Refs. 12, 16, 25, 30). Although using arc energy as a single variable shows surprising results compared to what is predicted with slowrate cooling predictions from the $\mathrm{Fe}-\mathrm{Cr}-\mathrm{Ni}$ pseudo binary phase diagram (Ref. 1), the total accumulative thermal cycles experienced locally in the root pass FZ of multipass welds in the form of multipass reheating cycles (Figs. 3A, $4 \mathrm{~A}, 4 \mathrm{C}$, and $5 \mathrm{~B}$ ) appears to have a more significant impact on austenite stabilization and evolution, including intragranular secondary austenite precipitation, than just arc energy per pass as a single variable.

The combined results of Experiments 2 and 3 show that increasing the number of thermal cycles with a constant arc en- ergy result in increased austenite content. First, direct experimental measurement of root-pass temperature during subsequent weld passes (Experiment 2) demonstrates for the chosen 4-pass weld conditions, weld passes 2, 3, and 4, all heat the root pass $\mathrm{FZ}$ above the critical temperature of $800^{\circ} \mathrm{C}\left(1472^{\circ} \mathrm{F}\right)$ - Fig. 4A. Second, the step-wise measurement of root-pass FZ austenite volume fraction at each of the 1-4 passes clearly correlates austenite increases with thermal cycles. Finally, the primary role of thermal cycle, suggested by Experiments 1 and 2, is definitively demonstrated by the Experiment 3 Gleeble reheating simulations of as-welded BOP microstructures performed with $98 \% \mathrm{Ar} / 2 \% \mathrm{~N}_{2}$ shielding gas. For both the aswelded microstructure in the root pass of Experiment 2 (Fig. $4 \mathrm{C}, 1$ ) and the BOP microstructure of Experiment 3 (Fig. 7E), thermal cycles change the microstructure from primarily grain boundary and Widmanstätten austenite morphology to one including pronounced intragranular secondary austenite content. Quantitatively, both experiments show increases in austenite content of about $10 \%$ as follows: Initial root pass austenite content of $43.5 \%$ increases to $53.5 \%$ in Experiment 2 , while the initial BOP austenite content of $37 \%$ increases to $47 \%$ after application of three total Gleeble reheating thermal cycles - Figs. $6 \mathrm{~B}$ and 8A, respectively. The austenite volume fraction increases $3-4 \%$ after each thermal cycle during the Gleeble experiments (Fig. 8A), for all shielding gas conditions, demonstrating the thermal cycle impact is additive to that of nitrogen content.

These findings are broadly consistent with previous studies that have focused on the impact of multipass welding on the root pass HAZ microstructures. For example, Tan simulated the root pass HAZ of a multipass weld by performing Gleeble thermal simulations using Rosenthal's heat transfer model (Ref. 6). They report a total 5\% increase in the root HAZ austenite volume fraction of a 12.7-mm (0.5-in.) single-V bevel geometry after the second and third subsequent passes, but with peak temperatures of $1050^{\circ} \mathrm{C}\left(1922^{\circ} \mathrm{F}\right)$ in the second pass and $700^{\circ} \mathrm{C}\left(1292^{\circ} \mathrm{F}\right)$ in the third pass, compared to the peak temperatures of $1218^{\circ} \mathrm{C}\left(2224^{\circ} \mathrm{F}\right)$ and $1065^{\circ} \mathrm{C}\left(1949^{\circ} \mathrm{F}\right)$ measured in this work (see Table 3) (Ref. 6). Ramirez draws a good correlation between Rosenthal's heat flow model and ex- 
perimental time and temperature gathered from the HAZ in three passes in GTA welds on 2205 DDSS (Ref. 27). His work shows that the HAZ in a root pass will increase in austenite upon reheating for both actual welds and Gleeble, which was observed in the FZ with Experiment 2 welds (Ref. 27).

Ramirez and Hosseini both report peak temperatures around $1000^{\circ} \mathrm{C}\left(1832^{\circ} \mathrm{F}\right)$ during the third pass for a 6-mm- (0.24-in.-) thick substrate (very close to temperatures collected by the thermocouples in the root FZ in Experiment 2 but in contrast to Tan's peak temperatures as shown previously) (Refs. 17, $23,27)$. The discrepancies of time and temperature data can be explained by the differences in joint thickness and geometry, which affect the heat flow and temperatures experienced in the root pass (Ref. 27). Other experiments measured the ferrite number (FN) in three pulsed 2205 and 2507 GMA welds over a GTAW root and report that the FN is highest in the top pass FZ and lowest in the second GMA pass FZ (Ref. 13), which is consistent with results in this work demonstrating the role of reheating to promote austenite formation. Finally, other studies that have focused on reheating effects in the HAZ or base metal in multipass welding (Refs. 6, 23, 24) demonstrate austenite content increases with thermal cycles.

Most of the increase in austenite upon reheating when observed with optical microscopy is characterized as intragranular secondary austenite (i.e., Fig. 2). Identification of the intragranular light regions as secondary austenite is consistent with previous studies of secondary austenite formation during Gleeble reheating thermal cycles (Refs. 3133). Secondary austenite should not be confused with primary intragranular austenite, which forms mostly in an aswelded microstructure - Fig. 7A, E, and I. Previous studies have shown that secondary austenite precipitates predominantly at temperatures of $1000^{\circ} \mathrm{C}\left(1832^{\circ} \mathrm{F}\right)$ on UNS S32750 and decreases at higher reheating temperatures above $1100^{\circ} \mathrm{C}\left(2012^{\circ} \mathrm{F}\right)$ (Ref. 33). Dissolution of intragranular (ferrite/ferrite) and intergranular (austenite/ferrite) chromium nitrides $\left(\mathrm{Cr}_{2} \mathrm{~N}\right)$ contribute to secondary austenite nucleation and growth, and longer times up to $10 \mathrm{~s}$ in between $900^{\circ}-1100^{\circ} \mathrm{C}\left(1652^{\circ}-2012^{\circ} \mathrm{F}\right)$ contribute to complete dissolution of $\mathrm{Cr}_{2} \mathrm{~N}$ and more secondary austenite formation (Ref. 31). However, only intragranular austenite is observed in this study. Thus, temperatures that rise above $900^{\circ} \mathrm{C}$ $\left(1652^{\circ} \mathrm{F}\right)$, such as temperatures seen with the third reheating cycle in Experiment 2, may cause heterogeneous nucleation of secondary austenite with UNS32750. Higher temperatures above $1100^{\circ} \mathrm{C}\left(2012^{\circ} \mathrm{F}\right)$ would cause grain growth of primary and secondary austenite upon reheating, but temperatures above the ferritization temperature (solidstate transformation temperature) may dissolve intragranular secondary austenite within the ferrite matrix. Therefore, reheating effects on nucleation and growth of primary and secondary austenite are sensitive to specific temperature ranges, depending on the composition and grade of duplex stainless steel.

Sigma phase can also form due to HAZ thermal cycles in the $828^{\circ}-1028^{\circ} \mathrm{C}$ temperature range, potentially leading to a loss of toughness and corrosion resistance in welded duplex stainless steels (Refs. 6, 17). While preliminary investigations for the presence of sigma phase were completed with optical microscopy of welds etched with Murakami reagent, the sigma phase was not observed. However, giv- en other investigators have reported formation of $0.24 \%$ sigma phase volume fraction for high arc energy (27 $\mathrm{kJ} / \mathrm{in}$.) and $0.06 \%$ for low arc energy (12 kJ/in.) after four passes in the reheated HAZ (Ref. 17), additional investigation of the impact of multipass welds on sigma phase formation in the root pass FZ is an opportunity for future work.

\section{Comparison of Chemical Composition and Thermal Effects}

While these results demonstrate that solid-state reheating increases austenite volume fraction in the root pass FZ, this data does raise one final question: Why do the highest arc energy welds of Experiment 1 have the lowest root pass austenite content (Fig. 5A)? It is hypothesized that these results showing a decrease in root pass austenite with increasing arc energy (Fig. 5A) are the consequence of two effects. First, as previously discussed, an increased arc energy results in fewer passes and reduces the number of solid-state reheating thermal cycles, hence reducing the final root pass austenite content. Second, it is hypothesized that increasing arc energy results in a reduction of austenite-stabilizing elements through the combined effects of dilution and nitrogen loss. Here, this second hypothesis is discussed.

Dilution increases as arc energy increases, which results in a decreasing benefit of the elevated nickel content in the ER2594 welding wire compared to the UNS 32750 SDSS base material (see Table 2). Additionally, increasing arc energy increases the weld pool size and yields slower cooling rates, thereby promoting nitrogen loss. As described in $\mathrm{Du}$ Toit's model (Ref. 34), a dynamic equilibrium exists in the nitrogen content of the nitrogen-enriched shielding gas, molten FZ, and adjacent HAZ. For a fixed nitrogen content in the shielding gas, increasing arc energy will promote nitrogen loss. For example, Hosseini demonstrated that in four autogenous weld passes, performed with the same arc energy (11.9 kJ/in.) over the same region in the SDSS, nitrogen was reduced from $0.28 \mathrm{wt}-\%$ in the base metal to $0.17 \mathrm{wt}-\%$ in the weld metal, corresponding to a decrease in austenite volume fraction from 45 to 25\% (Ref. 24). They report a higher arc energy ( $27.4 \mathrm{~kJ} / \mathrm{in}$.) resulted in a nitrogen loss of 0.28 to $0.10 \mathrm{wt}-\%$, which caused a decrease in austenite from 45 to $21 \%$ (Ref. 24). Furthermore, other studies have shown that welding with pure argon may result in a lower-than-desired austenite-ferrite ratio (Refs. 21, 24). Nitrogen loss is significant since a decrease in $0.05 \mathrm{wt}-\% \mathrm{~N}$ is reported to decrease the austenite content by as much as $10-15 \%$ (Refs. 16, 24). The addition of nitrogen to a shielding gas, which is claimed to increase the austenite content with the same arc energy, is interesting to understand from a reheating aspect (Ref. 21). It was found that increasing nitrogen content $\left(0-6 \% \mathrm{~N}_{2}\right)$ reveals higher austenite values among reheating (Fig. 8B), emphasizing the importance of shielding gas content selection for welding procedures specifications in multipass welding.

In summary, it is hypothesized that the initially surprising results of Fig. 5A, showing a decreasing root pass FZ austenite volume fraction with increasing arc energy, may be explained through the combined and synergistic effects of the following: 1) increasing arc energy reduces the number 
of solid-state reheating cycles because of higher deposition rates; 2) increasing arc energy increases dilution and thereby reduces the weld metal nickel content; and 3) increasing arc energy increases weld pool size and decreases cooling rates, which promote nitrogen loss.

\section{Implications of Results}

While previous studies have largely focused on the root pass HAZ because of loss of corrosion resistance (Refs. 14, $18,33,35-37)$, this paper focuses on metallurgical changes in the root FZ because of the initially unexpected results shown in Fig. 5. This work suggests that two primary factors are critical to controlling final microstructure and therefore weld metal properties: 1) weld metal composition and 2) solid-state reheating thermal cycles. As previously argued, for a given base alloy composition, final weld metal composition will be controlled by arc energy together with the chosen shielding gas nitrogen content and filler material through the combined effects of dilution and nitrogen evolution. While the initial FZ weld metal microstructure and austenite volume fraction are strongly affected by shielding gas nitrogen content (Fig. 7A, E, and I), thermal cycles play an additive effect on increasing the austenite content as shown by the Gleeble reheating data (Fig. 8A).

Understanding the differences with microstructural evolution in a thick-walled weld joint compared to a thin wall joint is important because cooling rates are faster in a thick wall joint with the same arc energy, which could have different microstructure behavior in the root than a thin wall joint (Ref. 25). Also, more reheating thermal cycles in the root occur with a thick wall joint than a thin wall joint (13 for thick and 3 for thin) as shown in Fig. 6B. Time and temperature data was only collected for five additional passes with the 12.7-mm- (0.5-in.-) thick weld, showing that the root gets to a peak just below $800^{\circ} \mathrm{C}\left(1472^{\circ} \mathrm{F}\right)$ at pass 6 (Fig. $6 \mathrm{~A}$ ). This data indicates that the root pass in thicker weld joints endure more thermal cycles and potential microstructure differences than a 6.3-mm- (0.25-in.-) thick weld. Also, Fig. 6B shows passes 1-13 (other than the top pass) experience reheating, which is evident in the average austenite volume fraction of $63.3 \%$ for passes $1,3,4,5$, and 8 . Table 3 and Fig. $6 \mathrm{~B}$ show that the second and third pass regions for the 6.3-mm (0.25-in.) multipass welds increase in austenite content as well as the root pass when reheated. Therefore, it is suggested that arc energy, the number of passes, joint configuration, deposition rate, dilution, shielding gas, and filler composition all be recognized as significant variables for microstructure development in all regions within a multipass weld, including both the root pass FZ and HAZ.

\section{Conclusions}

Based on this study, the following conclusions were made:

1) Reheating thermal cycles in multipass welds cause significant austenite vol-\% increase and morphology changes in the root pass fusion zone due to intragranular secondary austenite formation.

2) Total time spent in critical austenite temperature formation ranges has a significant impact on microstructure evolution in the root and subsequent passes.

3) The combined effects of chemical composition (through nitrogen gas additions and overalloyed nickel welding wire), arc energy (dilution), and thermal cycles contribute to the wide range in morphology and austenite content.

4) These results suggest that arc energy, the number of passes, dilution, shielding gas, and filler composition are all important variables to consider when designing welding procedures for successful joining and proper phase balance of superduplex stainless steels.

\section{Acknowledgments}

We thank Bechtel Global Corp. for financial support of initial work; Outokumpu and Böhler Welding for donation of UNS S32507 plates and filler materials, respectively; and Trinity Rail Industries for providing financial support for the DAQ system. We are grateful to Dr. Ben Pletcher, Dr. Yoni Adonyi, Balazs Varbai, Dr. Richard Campbell, and Dr. Jonathan Demko for useful discussions. We thank Christian Von Qualen, Michael Miller, and Reed Philips for experimental support.

\section{References}

1. Lippold, J. C., and Kotecki, D. J. 2005. Welding Metallurgy and Weldability of Stainless Steels. Hoboken, N.Y.: John Wiley \& Sons.

2. Westin, E. M. 2010. Pitting corrosion resistance of GTA welded lean duplex stainless steel. Welding in the World 54: R308-R321. https://www.doi.org/10.1007/BF03266745

3. Verma, J., and Taiwade, R. V. 2017. Effect of welding processes and conditions on the microstructure, mechanical properties and corrosion resistance of duplex stainless steel weldments - A review. Journal of Manufacturing Processes 25: 134-152.

https://www.doi.org/10.1016/j.jmapro.2016.11.003

4. Karlsson, L. 2012. Welding duplex stainless steels - A review of current recommendations. Welding in the World 56: 65-76. https://www.doi.org/10.1007/BF03321351

5. Tavares, S. S. M., Pardal, J. M., Lima, L. D., Bastos, I. N., Nascimento, A. M., and de Souza, J. A. 2007. Characterization of microstructure, chemical composition, corrosion resistance and toughness of a multipass weld joint of superduplex stainless steel UNS S32750. Materials Characterization 58: 610-616.

https://www.doi.org/10.1016/j.matchar.2006.07.006

6. Tan, H., Wang, Z., Jiang, Y., Yang, Y., Deng, B., Song, H., and Li, J. 2012. Influence of welding thermal cycles on microstructure and pitting corrosion resistance of 2304 duplex stainless steels. Corrosion Science 55: 368-377. https://www.doi.org/10.1016/j.corsci.2011. 10.-039

7. Ogawa, T., and Koseki, T. 1989. Effect of composition profiles on metallurgy and corrosion behavior of duplex stainless steel weld metals. Welding Journal 68(5): 181-s to 191-s.

8. Sieurin, H., Sandström, R., and Westin, E. M. 2006. Fracture toughness of the lean duplex stainless steel LDX 2101. Metallurgical and Materials Transactions A 37: 2975-2981. https://www.doi. org/10.1007/s11661-006-0179-7

9. Taban, E. 2008. Joining of duplex stainless steel by plasma arc, TIG, and plasma arc+TIG welding processes. Materials and Manufacturing Processes 23: 871-878. https://www.doi.org/ 10.1080/10426910802385075

10. Tehovnik, F., Arzenšek, B., Arh, B., Skobir, D., Pirnar, B., and Žužek, B. 2011. Microstructure evolution in SAF 2507 super duplex stainless steel. Materials and Technologies 45: 339-345. 
11. Topolska, S., and Labanowski, J. 2009. Effect of microstructure on impact toughness of duplex and superduplex stainless steels. Journal of Achievements in Materials and Manufacturing Engineering 36: 142-149.

12. Salminen, A., Westin, E., Lappalainen, E., and Unt, A. 2012. Effect of gas shielding and heat input on autogenous welding of duplex stainless steel. ICALEO ${ }^{\circledR}$ 2012: 524-531.

13. Bermejo, M. V., Karlsson, L., Svensson, L. E., Hurtig, K., Rasmuson, H., Frodigh, M., and Bengtsson, P. 2015. Effect of shielding gas on welding performance and properties of duplex and superduplex stainless steel welds. Welding in the World 59: 239249. https://www.doi.org/10.1007/s40194-014-0199-7

14. Zhang, Z., Jing, H., Xu, L., Han, Y., and Zhao, L. 2016. Investigation on microstructure evolution and properties of duplex stainless steel joint multipass welded by using different methods. Materials \& Design 109: 670-685. https://www.doi.org/10.1016/ j.matdes.2016.07.110

15. Sales, A. M., Westin, E. M., and Jarvis, B. L. 2017. Effect of nitrogen in shielding gas of keyhole GTAW on properties of duplex and superduplex welds. Welding in the World 61: 1133-1140. https://www.doi.org/10.1007/s40194-017-0486-1

16. Hsieh, R.-I., Liou, H.-Y., and Pan, Y.-T. 2001. Effects of cooling time and alloying elements on the microstructure of the Gleeble-simulated heat-affected zone of $22 \% \mathrm{Cr}$ duplex stainless steels. Journal of Materials Engineering and Performance 10: 526 536. https://www.doi.org/10.1361/105994901770344665

17. Hosseini, V. A., Bermejo, M. A. V., Gårdstam, J., Hurtig, K., and Karlsson, L. 2016. Influence of multiple thermal cycles on microstructure of heat-affected zone in TIG-welded super duplex stainless steel. Welding in the World 60: 233-245. https://www.doi. org/10.1007/s40194-016-0300-5

18. Mourad, A.-H. I., Khourshid, A., and Sharef, T. 2012. Gas tungsten arc and laser beam welding processes effects on duplex stainless steel 2205 properties. Materials Science and Engineering A 549: 105-113. https://www.doi.org/10.1016/j.msea.2012.04.012

19. Westin, E. M. 2010. Microstructure and properties of welds in the lean duplex stainless steel LDX 2101. PhD dissertation. Stockholm, KTH.

20. Muthupandi, V., Bala Srinivasan, P., Seshadri, S. K., and Sundaresan, S. 2004. Effect of nitrogen addition on formation of secondary austenite in duplex stainless steel weld metals and resultant properties. Science and Technology of Welding and Joining 9: 4752. https://www.doi.org/10.1179/136217104225017143

21. Westin, E. M., and Hertzman, S. 2014. Element distribution in lean duplex stainless steel welds. Welding in the World 58: 143160. https://www.doi.org/10.1007/s40194-013-0108-5

22. Westin, E. M., Grönlund, K., Runnsjö, G., and Cross, C. E. 2018. Use of electron microprobe analysis to explain metallurgical phenomena and their effect on properties when welding stainless steel. Welding in the World 62: 55-69. https://doi.org/10.1007/ s40194-017-0522-1

23. Hosseini, V. A., Hurtig, K., and Karlsson, L. 2017. Effect of multipass TIG welding on the corrosion resistance and microstructure of a super duplex stainless steel. Materials and Corrosion 68: 405-415. https://doi.org/10.1002/maco.201609102

24. Hosseini, V. A., Wessman, S., Hurtig, K., and Karlsson, L. 2016. Nitrogen loss and effects on microstructure in multipass TIG welding of a super duplex stainless steel. Materials and Design 98: 88-97. https://doi.org/10.1016/j.matdes.2016.03.011

25. Kotecki, D. J. 2010. Some pitfalls in welding of duplex stainless steels. Soldag. Insp. São Paulo 15: 336-343. https://doi.org/ 10.1590/S0104-92242010000400011

26. Wessman, S., and Selleby, M. 2014. Evaluation of austenite reformation in duplex stainless steel weld metal using computational thermodynamics. Welding in the World 58: 217-224.

https://doi.org/10.1007/s40194-013-0104-9

27. Ramirez, A. J., and Brandi, S. D. 2004. Application of dis- crete distribution point heat source model to simulate multipass weld thermal cycles in medium thick plates. Science and Technology of Welding and Joining 9: 72-82. https://doi.org/10.1179/ 136217104225017189

28. Roduit, N. 2008. JMicroVision: Image analysis toolbox for measuring and quantifying components of high-definition images, Version 1. Software available for free download at jmicrovision.com.

29. Lide, D. 2003. Handbook of Chemistry and Physics, $79^{\text {th }}$ Edition. New York, N.Y.: CRC Press.

30. Hertzman, S., Brolund, B., and Ferreira, P. J. 1997. An experimental and theoretical study of heat-affected zone austenite reformation in three duplex stainless steels. Metallurgical and Materials Transactions A 28: 277-285. https://doi.org/10.1007/s11661-997-0130-6

31. Ramirez, A. J., Lippold, J. C., and Brandi, S. D. 2003. The relationship between chromium nitride and secondary austenite precipitation in duplex stainless steels. Metallurgical and Materials Transactions A 34: 1575-1597. https://doi.org/10.1007/s11661003-0304-9

32. Garzón, C. M., and Ramirez, A. J. 2006. Growth kinetics of secondary austenite in the welding microstructure of a UNS S32304 duplex stainless steel. Acta Materialia 54: 3321-3331. https://doi.org/10.1016/j.actamat.2006.03.018

33. Ramirez, A. J., Brandi, S. D., and Lippold, J. C. 2004. Secondary austenite and chromium nitride precipitation in simulated heat affected zones of duplex stainless steels. Science and Technology of Welding and Joining 9: 301-313. https://doi.org/10.1179/ 136217104225021715

34. Du Toit, M., and Pistorius, P. C. 2003. Nitrogen control during autogenous arc welding of stainless steel - Part 1: Experimental observations. Welding Journal 82(8): 219-s to 224-s.

35. Ramkumar, K. D., Oza, S., Periwal, S., Arivazhagan, N., Sridhar, R., and Narayanan, S. 2014. Characterization of weld strength and impact toughness in the multipass welding of super-duplex stainless steel UNS 32750. Materials and Design 60: 125-135. https://doi.org/10.1016/j.ctmat.2015.04.004

36. Sieurin, H., and Sandström, R. 2006. Austenite reformation in the heat-affected zone of duplex stainless steel 2205. Materials Science and Engineering A 418: 250-256. https://doi.org/10.1016/ j.msea.2005.11.025

37. Zhang, Z., Jing, H., Xu, L., Han, Y., Zhao, L., and Zhang, J. 2017. Influence of microstructure and elemental partitioning on pitting corrosion resistance of duplex stainless steel welding joints. Applied Surface Science 394: 297-314. https://doi.org/10.1016/ j.apsusc.2016.10.047

TIMOTHY PICKLE, NICHOLAS HENRY, PETER MORRISS, LOGAN TENNIS, and DAVID WAGNER are undergraduate research students, and RICHARD E. BAUMER (richardbaumer@letu.edu) is the Omer Blodgett chair of welding and materials joining engineering, at LeTourneau University, Department of Welding/ Materials Joining Engineering, Longview, Tex. 